\title{
ESTIMATION OF DRIFT LIMITS FOR DIFFERENT SEISMIC DAMAGE STATES OF TYPICAL SINGLE-STORY PRECAST RC BUILDINGS
}

\author{
${ }^{1}$ Ali Yesilyurt, ${ }^{1}$ M. Rizwan Akram, ${ }^{2}$ A. Can Zulfikar and ${ }^{3}$ Cuneyt Tuzun \\ ${ }^{1} \mathrm{PhD}$. Students., Earthquake and Structural Eng. Department, Gebze Technical University,Turkey \\ ${ }^{2}$ Asst. Prof. Dr., Department of Civil Engineering, Gebze Technical University,Turkey \\ ${ }^{3}$ Instructor, Department of Civil Engineering, Gebze Technical University,Turkey \\ Corresponding email: aliyesilyurt@gtu.edu.tr
}

\begin{abstract}
In the past earthquakes, the field surveys performed on the single-story precast RC industrial buildings reveal that the main reason for severe damages in those structures were due to the insufficient lateral stiffness. These high period structures exhibit more flexible behavior than conventional reinforced concrete structures. In this study, different code status single story precast RC industrial building models have been considered. Limit drift values for four different damage states such as slight, moderate, extensive, and complete have been investigated based on Park and Ang damage index values. These damage index values are obtained from incremental dynamic analysis. Incremental dynamic analysis is conducted for 25 earthquake ground motion records. The results of current study show that there is an increase in mean drift values obtained for each damage case taken from low code to high code. In the final step, values of current study are also examined in comparison with the values recommended for low-rise prefabricated building class in HAZUS. It is believed that the limit drift values presented in the study will allow a practical and rapid evaluation of the vulnerability of the considered structure.
\end{abstract}

Key words: Vulnerability, Damage index, Incremental dynamic analysis

\section{Introduction}

Due to safety, low-cost and rapid construction, the use of single-story prefabricated industrial buildings is quite common in Turkey. Demand of these structures is increasing day by day due to short construction time as compared with the conventional RC structures. Moreover, the construction materials are obtained by pre-production in factories that provides large internal volume at low costs.

In comparison of seismic behavior aspect with the traditional $\mathrm{RC}$ residential buildings, the single-story precast RC-industrial structures show more flexibility along with rigid diaphragm behavior that is infrequent. In general, these industrial buildings have rectangular and symmetrical forms and different number of spans [1]. As the result of field surveys, it is seen that the commonly used geometric configuration is either single or multi-spans in the precast roof girder orientation and multi-bays in the direction perpendicular to the precast roof girder direction. (Fig. 1.).

A potential earthquake can cause significant damages to precast RC structures in industrial zones, which may have a directly or indirectly impact on the economy of the region. Direct damages can be listed as permanent deformations of structural elements and losses in systems 
such as hardware, mechanical, electrical and installation. The indirect economic loss is socioeconomic losses due to production disruptions and business interruptions.

In past seismic events of Turkey, extreme damages have been observed in single story precast RC structures due to their poor performance behavior[2]. Major structural deficiencies of RC precast industrial structures are seen in 1998 Adana-Ceyhan[3], 1999 Kocaeli and Duzce earthquakes [4,5] and the October 23, 2011 Van earthquake[6] due to insufficient stiffness, ductility, and strength conditions. The seismic displacement demand of the considered industrial buildings is larger compared to traditional reinforced concrete frame structures due to their higher flexibility both for higher square column height and a cantilevered construction configuration[7].

The commonly used single story precast RC industrial buildings vary from country to country and even inside the same country based on the region of their availability. Therefore, structural vulnerability with analytical methods should be considered separately. Damage parameters generally used in vulnerability assessments are; damage index [8,9], inter-story drift ratio[10,11], strain limit of the concrete and longitudinal reinforcement[12].

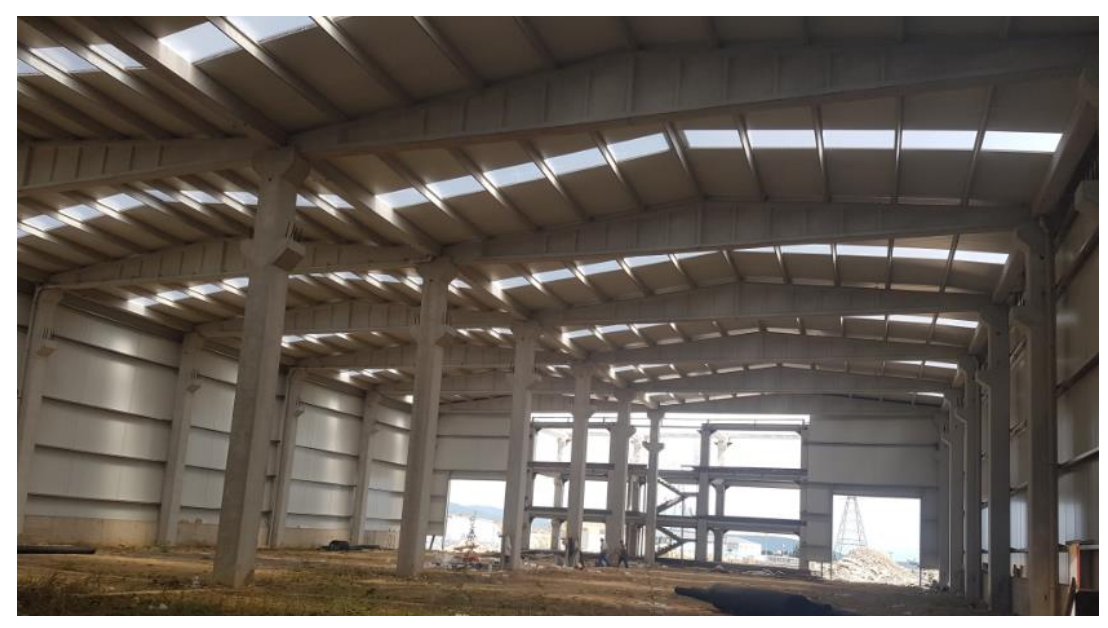

Fig.1 The general view of a typical single story precast industrial RC-building

Damage index parameter is usually preferred for evaluating the vulnerability of structures. The subject parameter can be obtained from different models [13-15]. The commonly used method is named as "The Park and Ang Damage Index Model" and is given in Eq.1.

$$
D I_{P \& A}=\frac{\delta_{m}}{\delta_{u}}+\frac{\beta}{\delta_{u} * P_{y}} * \int d E_{h}
$$

In Eq.1., $\delta_{m}$ is the maximum experienced deformation, $\delta_{u}$ is the ultimate deformation of the element, $P_{y}$ is the yield strength of the element, $\int d E_{h}$ is the cumulative hysteretic energy absorbed by the element for the duration of time history analysis, and the last parameter $\beta$ is a model constant [15].

In this study, modified Park and Ang damage model has been used. This model is revised by Kunnath et. al [16]. The mathematical representation of the improved DI model is given in Eq.2.

$$
D I=\frac{\theta_{m}-\theta_{r}}{\theta_{u}-\theta_{r}}+\frac{\beta}{\theta_{u} * M_{y}} * E_{h}
$$


In Eq.2., $\theta_{\mathrm{m}}$ is the maximum rotation achieved during the loading history, $\theta_{\mathrm{u}}$ is the ultimate rotation capacity of the section, $\theta_{\mathrm{r}}$ is the recoverable rotation during unloading, $\mathrm{M}_{\mathrm{y}}$ is the yield moment, and $\mathrm{E}_{\mathrm{h}}$ is the cumulative dissipated energy in the section.

To evaluate the vulnerability for different building classes, earthquake loss estimation methodology (HAZUS, 2001) has made general classifications of many building types by considering the code and structural heights. Limit values for different damage states of building classes are different damage parameters; presented for spectral displacement, interstory drift ratio etc. [17].

In this study, different geometric feature single story precast RC industrial buildings usually preferred in organized industrial zone in turkey are considered. The relationship between DI and drift is investigated for 3 different code states of these structures. As a result of analyzes completed by IDA method, the drift limit values are obtained for 4 different damage states by considering DI parameter. The drift values obtained within the scope of current study are then examined in comparison with the recommended values for the PC2L building class, which is defined as the low-rise prefabricated building class in HAZUS.

\section{Seismic input data and analysis procedure}

According to the Turkish Building Seismic Design Code 2018 (TBSDC-2018), a seismic hazard level with $10 \%$ probability of exceedance has been assigned and Seismic Design Level-1 have been identified [18]. Total 25 earthquake ground motion records are selected from Pacific Earthquake Engineering Research (PEER) Center database [19] and these records are prepared for the analysis. Detailed information of the ground motion database considered in the analysis is given in Table 1.

Table 1. Detailed information of earthquake ground motion records

\begin{tabular}{|l|l|l|c|c|c|}
\hline No & Earthquake name & Station & Dist.(km) & Vs30 & PGA $(\mathrm{g})$ \\
\hline 1 & Northern Calif-01,1941 & Ferndale City Hall(225) & 44 & 219.3 & 0.39 \\
\hline 2 & Northern Calif-01,1941 & Ferndale City Hall(315) & 44 & 219.3 & 0.41 \\
\hline 3 & Northern Calif-03,1954 & Ferndale City Hall(44) & 26 & 219.3 & 0.33 \\
\hline 4 & San Fernando,1971 & Whittier Narrows Dam(143) & 39 & 298.7 & 0.44 \\
\hline 5 & San Fernando,1971 & Whittier Narrows Dam(233) & 39 & 298.7 & 0.38 \\
\hline 6 & Imperial Valley-06,1979 & Calipatria Fire Station(225) & 23 & 205.8 & 0.42 \\
\hline 7 & Imperial Valley-06,1979 & Calipatria Fire Station(315) & 23 & 205.8 & 0.39 \\
\hline 8 & Imperial Valley-06,1979 & El Centro Array \#13,(230) & 21 & 249.9 & 0.38 \\
\hline 9 & Imperial Valley-06,1979 & Niland Fire Station(90) & 35 & 212.0 & 0.38 \\
\hline 10 & Imperial Valley-06,1979 & Niland Fire Station(360) & 35 & 212.0 & 0.37 \\
\hline 11 & Coalinga-01,1983 & Parkfield - Cholame 3W(300) & 44 & 230.6 & 0.39 \\
\hline 12 & Coalinga-01, 1983 & Parkfield - Cholame 4AW(0) & 46 & 283.4 & 0.37 \\
\hline 13 & Coalinga-01, 1983 & Parkfield - Cholame 4AW(90) & 46 & 283.4 & 0.39 \\
\hline 14 & Coalinga-01, 1983 & Parkfield - Cholame 5W(270) & 48 & 236.6 & 0.36 \\
\hline 15 & Coalinga-01, 1983 & Parkfield - Cholame 5W(360) & 48 & 236.6 & 0.35 \\
\hline 16 & Coalinga-01, 1983 & Parkfield - Fault Zone 3(0) & 36 & 211.7 & 0.34 \\
\hline 17 & Coalinga-01, 1983 & Parkfield - Fault Zone 3(90) & 36 & 211.7 & 0.33 \\
\hline 18 & Coalinga-01, 1983 & Parkfield - Fault Zone 6(90) & 31 & 266.7 & 0.37 \\
\hline 19 & Coalinga-01, 1983 & Parkfield - Gold Hill 1W(0) & 35 & 214.4 & 0.34 \\
\hline 20 & Coalinga-01, 1983 & Parkfield - Gold Hill 6W(90) & 47 & 232.4 & 0.40 \\
\hline 21 & Coalinga-01, 1983 & Parkfield - Vineyard Cany 1W(0) & 27 & 284.2 & 0.39 \\
\hline 22 & Coalinga-01, 1983 & Parkfield - Vineyard Cany 1W(90) & 27 & 284.2 & 0.37 \\
\hline 23 & N. Palm Springs,1986 & Indio - Coachella Canal(0) & 41 & 339.0 & 0.40 \\
\hline 24 & N. Palm Springs,1986 & Indio - Coachella Canal(90) & 41 & 339.0 & 0.40 \\
\hline 25 & N. Palm Springs,1986 & San Jacinto - Valley Cemetary(360) & 30 & 330.7 & 0.44 \\
\hline
\end{tabular}


The damage model developed by Kunnath et. al [16] based on IDA method is already given in Eq.2 validated for each building model and here below is the brief explanation related to each step achieved in evaluation.

- Selection of ground motion record to be used in the analysis ( $\ddot{u}_{g}(t)$ )

- Determination of intensity parameter (Sa (T1)), the analysis of the spectral acceleration value corresponding to the dominant period of the considered structure is repeated from $0.05 \mathrm{~g}$ to $2.0 \mathrm{~g}$ in increments of $0.05 \mathrm{~g}$ in each step. In buildings with low code status, increments of less than $0.05 \mathrm{~g}$ have been made to determine the damage states more clearly.

- The model whose analysis was completed after each increment of the considered earthquake record, DI and drift values are obtained.

- The steps described above are repeated for all earthquake records given in Table 1 and the analyzes for the structure are completed.

The threshold values defined by The Park and Ang [13] for the different damage states in the considered structure of the DI values are given in Table 2.

Table 2. Characterization of damage states based on threshold values

\begin{tabular}{lc}
\hline \multicolumn{1}{c}{ Degree of Damage } & Damage Index \\
\hline None & $<0.10$ \\
Slight & $0.10-0.20$ \\
Moderate & $0.20-0.40$ \\
Extensive & $0.40-1.0$ \\
Complete & $>1.0$ \\
\hline
\end{tabular}

In this study, structural frames are composed of cantilever columns with rigid joints at the foundation level. At the top of column, the pre-stressed precast beams have got pinned connections so that during seismic action no additional moments are transmitted between them. During the analysis of such structures, the rigid diaphragm feature is rare to be observed, therefore, it can be acceptable to consider the models as 2D. Additionally, nonlinear dynamic analysis was performed using IDARC2D[15].

\section{Damage Index vs Drift Values Distribution}

The geometrical features of commonly used single story precast RC industrial buildings in Turkey are studied with the existing structures in industrialized regions and prevalent geometrical features are identified. Then, considering the strength and ductility parameters, three different code states; low, moderate and high code are assigned. For each code case, the IDAs of four different structures have been carried out considering the procedure described in prior section. The scattering of drift values for damage index limit values of different damage states given in Table 2 are presented in Figure 2-4. 

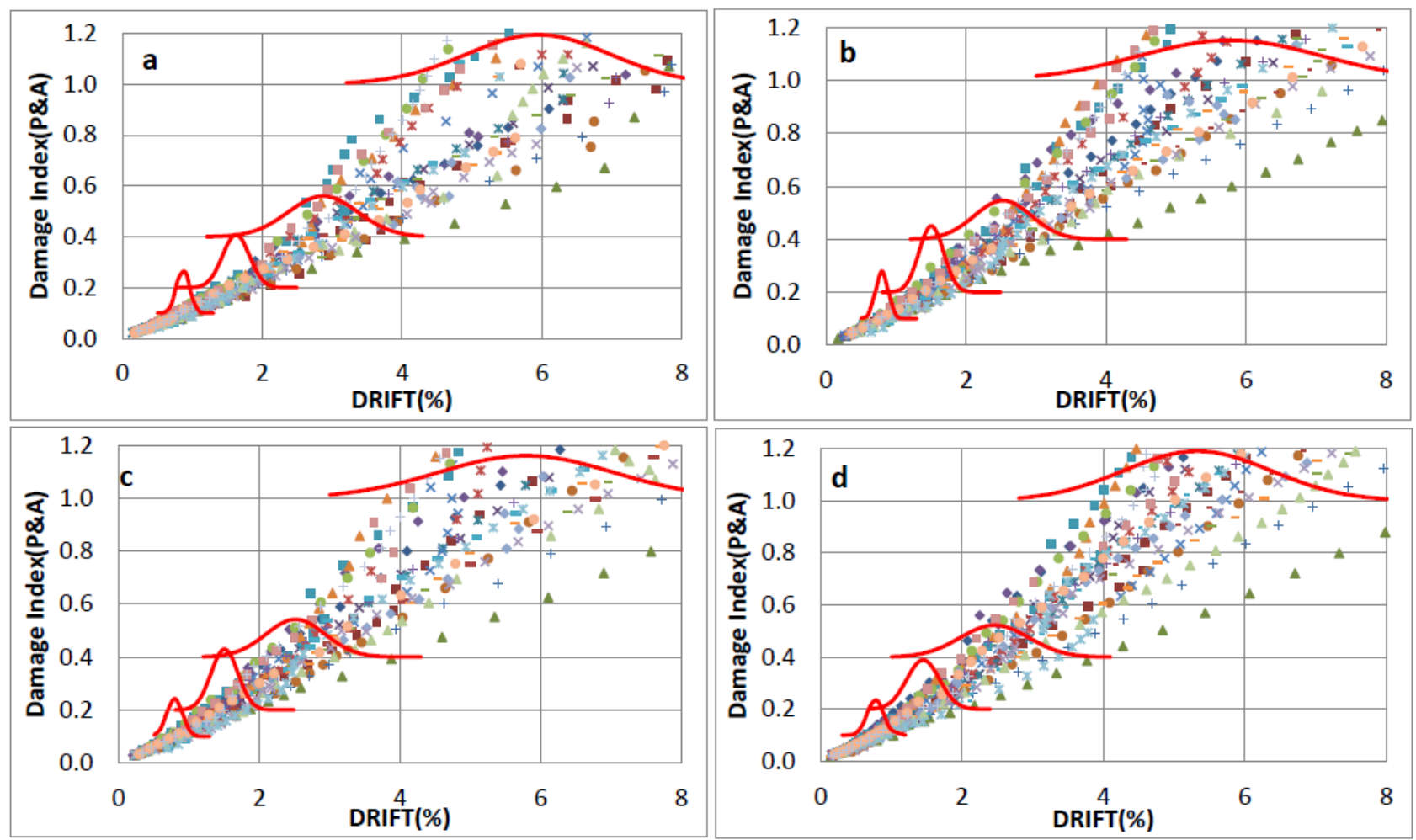

Figure 2. DI-Drift relationship obtained for four different structures with low code properties
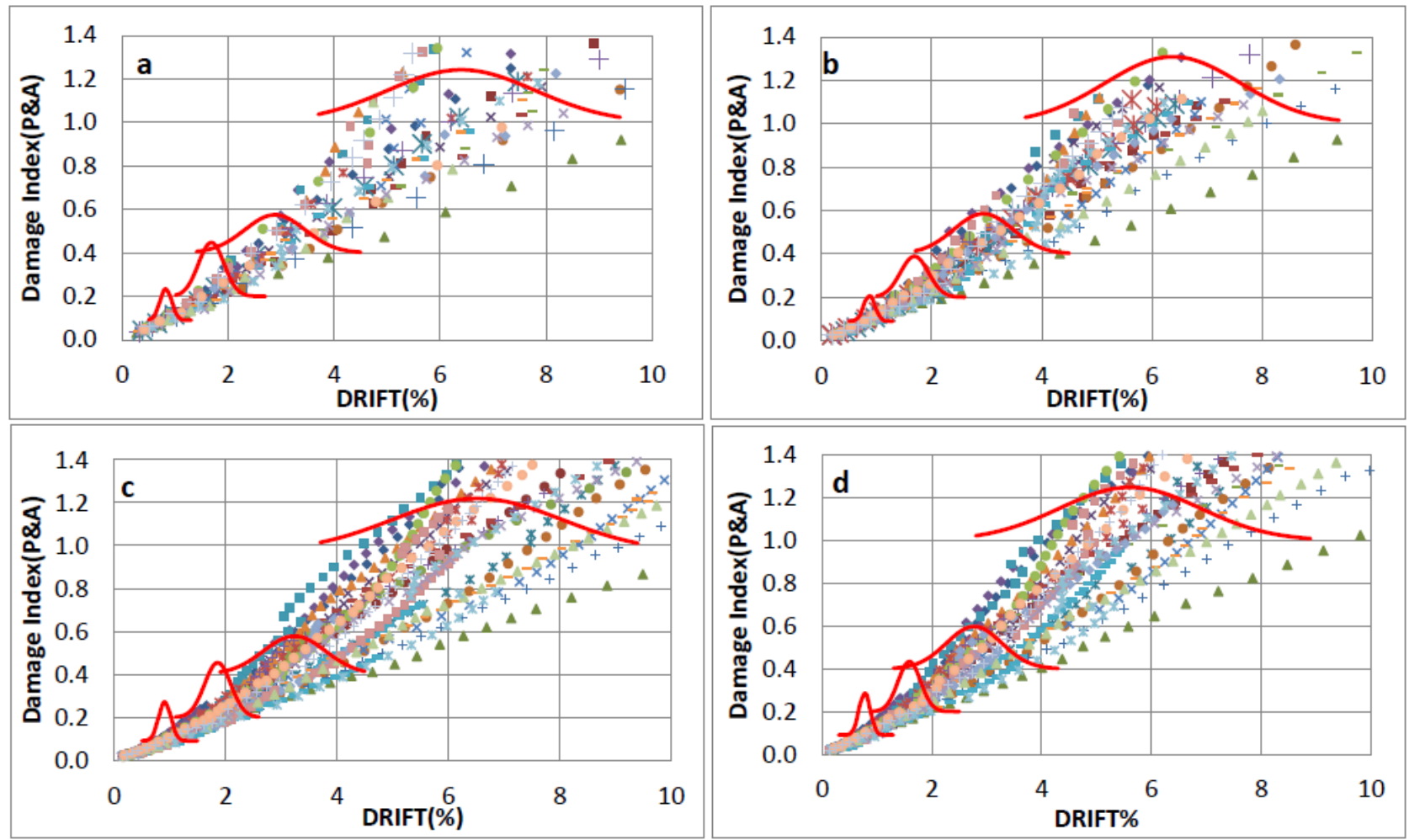

Figure 3. DI-Drift relationship for four different structures with moderate code properties 


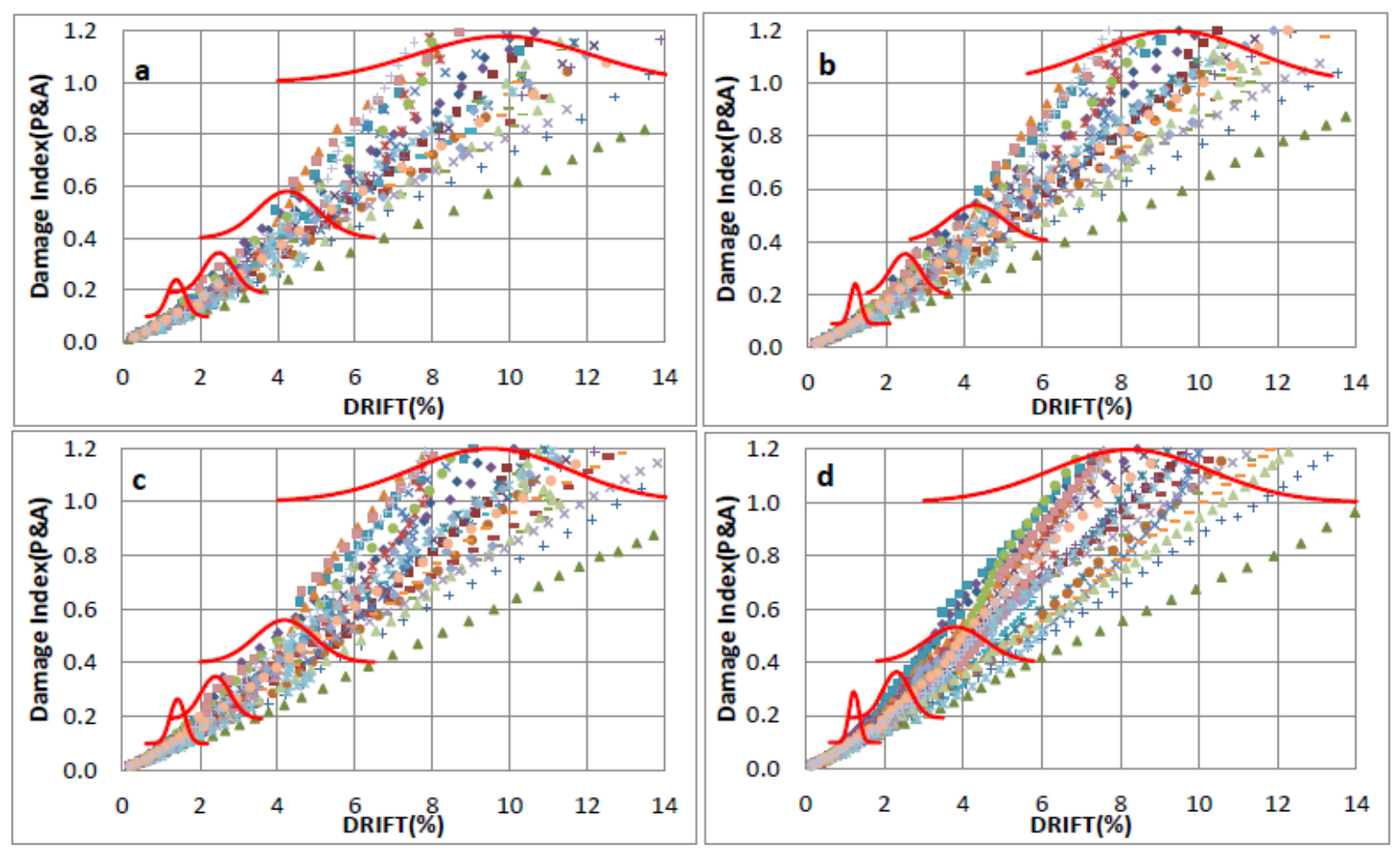

Figure 4. DI-Drift relationship for different structures with high code properties

The mean and standard deviation of the drift values obtained for different damage states of the analyzed structures are given in Table 3 . The 'C (column)' structure given in Table 3 refers to the square column size, HR to Heavy roof and LR as Light roof type. In examination of complete values, it is seen that there is an increase in mean drift values obtained for each damage case taken from low code to high code. There are minor differences occur between mean limit drift values obtained for low code and moderate code, however it is seen that there are more dramatic increases as high code is passed. It is also seen from Fig.2-4 and Table 3 that the drift scatter increases as it continues from slight to the complete damage state.

Table 3. Average and standard deviation of the obtained drift values for 4 different damage states of different structures with different code states

\begin{tabular}{|c|c|c|c|c|c|c|c|c|c|c|}
\hline & & & \multicolumn{8}{|c|}{ Interstory Drift Ratio for Damage States } \\
\hline & & \multirow[b]{2}{*}{ Building } & \multicolumn{2}{|c|}{ Slight } & \multicolumn{2}{|c|}{ Moderate } & \multicolumn{2}{|c|}{ Extensive } & \multicolumn{2}{|c|}{ Complete } \\
\hline & & & Mean & St. Dev. & Mean & St. Dev. & Mean & St. Dev. & Mean & St. Dev. \\
\hline \multirow{4}{*}{$\begin{array}{l}\text { Low-Code } \\
\text { SDL }\end{array}$} & a & C40-HR & 0.865 & 0.092 & 1.624 & 0.193 & 2.868 & 0.500 & 5.946 & 1.027 \\
\hline & $\mathrm{b}$ & $\mathrm{C} 45-\mathrm{HR}$ & 0.799 & 0.090 & 1.505 & 0.175 & 2.528 & 0.410 & 5.777 & 1.319 \\
\hline & $\mathrm{c}$ & C50-HR & 0.795 & 0.112 & 1.505 & 0.191 & 2.515 & 0.423 & 5.792 & 1.246 \\
\hline & $\mathrm{d}$ & C60-HR & 0.775 & 0.117 & 1.455 & 0.232 & 2.466 & 0.489 & 5.328 & 1.041 \\
\hline \multirow{4}{*}{$\begin{array}{l}\text { Moderate- } \\
\text { Code SDL }\end{array}$} & $\mathrm{a}$ & $\mathrm{C} 40-\mathrm{HR}$ & 0.818 & 0.109 & 1.678 & 0.243 & 2.885 & 0.570 & 6.400 & 1.402 \\
\hline & $\mathrm{b}$ & C50-HR & 0.868 & 0.101 & 1.688 & 0.255 & 2.940 & 0.537 & 6.386 & 1.228 \\
\hline & $\mathrm{c}$ & C50-LR & 0.907 & 0.111 & 1.862 & 0.235 & 3.238 & 0.562 & 6.524 & 1.523 \\
\hline & $\mathrm{d}$ & C60-HR & 0.776 & 0.101 & 1.591 & 0.206 & 2.773 & 0.504 & 5.608 & 1.282 \\
\hline \multirow{4}{*}{$\begin{array}{l}\text { High-Code } \\
\text { SDL }\end{array}$} & $\mathrm{a}$ & C45-HR & 1.381 & 0.226 & 2.482 & 0.390 & 4.251 & 0.775 & 9.823 & 2.249 \\
\hline & $\mathrm{b}$ & C50-HR & 1.210 & 0.132 & 2.408 & 0.388 & 4.289 & 0.720 & 9.353 & 2.026 \\
\hline & $\mathrm{c}$ & C55-HR & 1.425 & 0.191 & 2.402 & 0.380 & 4.186 & 0.754 & 9.493 & 2.021 \\
\hline & $\mathrm{d}$ & C60-LR & 1.232 & 0.124 & 2.310 & 0.347 & 3.816 & 0.758 & 8.247 & 2.013 \\
\hline
\end{tabular}




\section{Comparison of Propose Limit Drift Values with Recommended Values in HAZUS}

It is essential to state that the limit values of the damage parameters presented for different damage states of various building classes allow risk assessment and clarify the main target of the study. At this point, building capacity and vulnerability curves available in HAZUS (2001) are commonly used worldwide in their modification forms.

As previously expressed, nonlinear dynamic analyses was performed for each code status of four buildings. Mean drift values corresponding to obtained DI values for any damage case considered are extracted.

Table 4. Comparison of obtained limit values in current study to the HAZUS (2001) report.

\begin{tabular}{lcccc|crrr}
\hline \multicolumn{8}{c}{ Inter-story Drift at Threshold of Damage State } \\
\hline & \multicolumn{3}{c}{ In HAZUS } & \multicolumn{4}{c}{ Current Study } \\
\hline \multirow{2}{*}{ Low-Code SDL } & 0.0050 & 0.0080 & 0.0201 & 0.0547 & 0.0081 & 0.0152 & 0.0259 & 0.0571 \\
Moderate-Code SDL & 0.0050 & 0.0087 & 0.0234 & 0.0656 & 0.0084 & 0.0170 & 0.0296 & 0.0623 \\
High-Code SDL & 0.0050 & 0.0100 & 0.0300 & 0.0875 & 0.0131 & 0.0240 & 0.0414 & 0.0923 \\
\hline
\end{tabular}

In Table 4. drift limit values for 4 damage states are presented for both taken from HAZUS and from the current study analysis. The drift limit values derived from HAZUS are for lowrise prefabricated building class that comes under the category of P2CL. Others are for single story precast RC buildings of current study. As drift limit values in HAZUS are dependent on general classification, analysis method, performance level of structures that can vary from the current study. Therefore, it is general to notice difference in the output values for comparison. In the examination of drift values obtained in current study for different damage states reveal that the output values are reasonable. The purpose of this study is to test the compatibility of the values obtained before considering the more extensive inventory of structures. The result of current study proves that the damage values are at reasonable levels.

\section{Conclusions}

In this study, the drift limit values are investigated for different damage states considered for single story precast RC industrial buildings. Different structures with low, moderate and high codes using IDA method are taken into consideration. Drift values are obtained for the damage state by taking the DI parameter as reference, which is frequently used in the assessment of the vulnerability of the structures. It is seen that there is an increase in mean drift values obtained for each damage case taken from low code to high code. Further, minor differences occur between mean limit drift values for low code and moderate code, however there are dramatic increases when high code is passed. These values are then comparatively analyzed with the HAZUS (2001) report values suggested for PC2L structure class and the results were found to be reasonable. Therefore, more detailed evaluations of the method presented in the study can be tested by being taken into account a comprehensive building inventory. In addition, it is thought that the limit drift values presented in the study will allow a practical and rapid evaluation of the vulnerability of the considered structure.

\section{References}

[A1] Casotto, Chiara, et al. "Seismic fragility of Italian RC precast industrial structures." Engineering Structures 94 (2015): 122-136. 
[A2] Arslan, M., H., Korkmaz H., Gülay F., G., Damage and failure pattern of prefabricated structures after major earthquakes in Turkey and shortfalls of the Turkish Earthquake Code, Engineering Failure Analysis, Elsevier, 13, 2006.

[A3] Adalier, K., and Aydingun, O. (2001). "Structural engineering aspects of the June 27, 1998 Adana-Ceyhan (Turkey) earthquake.” Engineering Structures, 23(4), 343-355.

[A4] Saatcioglu, M., Mitchell, D., Tinawi, R., Gardner, N. J., Gillies, A. G., Ghobarah, A., Anderson, D.L., and Lau, D. (2001). "The August 17, 1999 Kocaeli (Turkey) earthquakedamage to

structures.” Canadian Journal of Civil Engineering, 28(8), 715-773.

[A5] Sezen, H., and Whittaker, A. S. (2006). "Seismic performance of industrial facilities affected by the 1999 Turkey earthquake." Journal of Performance of Constructed Facilities, 20(1), 28-36.

[A6] Ozden, S., Akpinar, E., Erdogan, H., \&Atalay, H. (2014).Performance of precast concrete structures in October 2011 Van earthquake, Turkey. Magazine of Concrete Research, 66(11), 543-552.

[A7] Belleri, A., Brunesi, E., Nascimbene, R., Pagani, M., and Riva, P. (2014). "Seismic Performance of Precast Industrial Facilities Following Major Earthquakes in the Italian Territory." J. Perform. Constr. Facil., 10.1061/(ASCE)CF.1943-5509.0000617, 04014135.

[A8] [40] Dumova-Jovanoska E.. Fragility curves for reinforced concrete structures in Skopje (Macedonia) region. Soil Dyn \& Earthq Eng 2000; 19(6): 455-466.

[A9] Carrillo, J. (2015). Damage index based on stiffness degradation of low-rise RC walls. Earthquake Engineering \& Structural Dynamics, 44(6), 831-848.

[A10]Kirçil, M. S., \&Polat, Z. (2006).Fragility analysis of mid-rise R/C frame buildings.Engineering Structures, 28(9), 1335-1345.

[A11] Kircher CA, Nassar AA, Kustu O and Holmes WT. Development of building damage functions for earthquake loss estimation. Earthq Spectra 1997; 13(4):663-80.

[A12]Eren, C., \&Luş, H. (2015). A risk based PML estimation method for single-storey reinforced concrete industrial buildings and its impact on earthquake insurance rates. Bulletin of Earthquake Engineering, 13(7), 2169-2195.

[A13] Park YJ, Reinhorn AM \& Kunnath SK. IDARC: Inelastic damage analysis of reinforced concrete frame-shear-wall structures. Technical report NCEER-87-0008, State University of New York, Buffalo. (1987T)

[A14] Kunnath SK, Reinhorn AM, Lobo RF. IDARC version 3.0: A program for the inelastic damage analysis of Reinforced Concrete structures. Report No. NCEER-92-0022, National Center for Earthquake Engineering Research, University at Buffalo, The State University of New York. 1992b.

[A15] Reinhorn A M, Roh H, Sivaselvan M, Kunnath SK, Valles R E, Madan A and Park YJ. IDARC2D Version 7.0: A Program for the Inelastic Damage Analysis of Structures (MCEER09-0006); 2009. 
[A16] Kunnath SK, Reinhorn AM, Lobo RF. IDARC version 3.0: A program for the inelastic damage analysis of Reinforced Concrete structures. Report No. NCEER-92-0022, National Center for Earthquake Engineering Research, University at Buffalo, The State University of New York. 1992b.

[A17] Federal Emergency Management Agency (FEMA) (2001) HAZUS 99, earthquake loss estimation methodology, technical and user's manual, Washington, DC

[A18] TBSDC-2018 (2018) Turkish Building Seismic Design Code, Disaster and Emergency Management Authority. Ankara

[A19] Pacific Earthquake Engineering Research Center-PEER retrieved from peer.berkeley.edu/ 